EGU Stephan Mueller Special Publication Series, 3, 121-133, 2002

(C) European Geosciences Union 2002

\title{
The Neogene history of the Transylvanian basin in relation to its surrounding mountains
}

\author{
C. Sanders *, R. Huismans, J. D. van Wees, and P. Andriessen \\ Institute of Earth Sciences, Vrije Universiteit, De Boelelaan 1085, 1081 HV Amsterdam, The Netherlands \\ *Now at: Technical Geoscience Department, Petronas Carigali Sdn Bhd, Petronas Twin Towers, 50088 Kuala Lumpur, \\ Malaysia
}

Received: 2 May 2000 - Accepted: 7 January 2002

\begin{abstract}
The structural and subsidence history of the Neogene Transylvanian basin is reviewed in order to analyse its relation to the tectonic and erosional history of the surrounding Carpathian mountains that has been defined by apatite fission track data from previous studies. The main processes studied are redistribution of mass by erosion, and tectonic loading. A mass balance is calculated between material eroded from the mountains and material deposited in the sedimentary basin. The mass balance fits to within $20 \%$ and confirms the restricted nature of the Transylvanian basin from Late Badenian to Pannonian, and directly links the mass transfer from the tectonically active mountains to the coevally subsiding basin. From Pliocene to recent both the basin and the now tectonically inactive mountains have been eroding leading to a change in the mass redistribution and isostatic uplift of the basin.

Numerical flexural-isostatic 3-D modelling is used to study the effect of loading and subsequent unloading of the lithosphere as a consequence of the mass transfers by tectonic and erosional processes. From Badenian to Pannonian the combined load of the surrounding mountains and the basin fill lead to a minimum of $2 \mathrm{~km}$ of basin subsidence. During this period the Transylvanian basin can be regarded as a retro foreland basin of the Carpathian mountain belt. From Pliocene to recent the erosianal abrasion of both the mountains and the basin lead to a isostatic uplift of the basin surface between 300 and $500 \mathrm{~m}$. The modelling results fit well with apatite fission track constraints, the subsidence history of the basin and field observations on structures and paleostress. The quantitative approach constrains the processes that dominated the formation of the Transylvanian basin since the Late Badenian and explain its present day enigmatic relative high altitude of $400 \mathrm{~m}$ above sealevel.
\end{abstract}

Correspondence to: C. Sanders

(carloandre@petronas.com.my)

\section{Introduction}

The tectonic origin of the Transylvanian Basin in Romania is ill-defined. Because of its coincidence in time and place with the neighbouring Pannonian basin they have been tentatively explained as sister basins, assuming similar tectonic histories for both basins. The Pannonian and Transylvanian basin are both molasse basins situated in the interior of the Carpathian orocline (Fig. 1). They subsided simultaneously during the Mid- and Late Miocene and have a similar biostratigraphy as part of the Central Paratethys system (Steininger et al., 1988).

However a closer look at the main features of the Pannonian- and Transylvanian basin quickly learns that the two basins are more different then alike. Contrary to the Pannonian basin, the Transylvanian Basin has a low surface heat flow, is situated on top of a moderately thick continental crust (e.g. Horvath, 1993), lacks major extensional structures and has a high present day mean surface elevation of $400 \mathrm{~m}$ above sealevel. The Transylvanian basin therefore most likely has a different tectonic origin compared to the Pannonian basin.

The Transylvanian basin is on all sides surrounded by mountainous regions. The Carpathians on its north, east and south side and the Apuseni mountains on its western side. The present day Romanian Carpathian topographic mountain belt originates from the Miocene (Sanders et al., 1999; Sanders, 1998), although its tectonic history dates back to the Cretaceous (e.g. Sandulescu, 1988; Ellouz and Roca, 1994). The Romanian Carpathians form a fold-and-thrust belt which has been thrusted over both the foreland and retro-foreland since the Late Badenian (Stefanescu, 1976; Sanders et al., 1999; Roure et al., 1993) (Fig. 2). It has been interpreted as a doubly vergent critical wedge (e.g. Platt, 1986; Davis et al., 1983; Willet et al., 1993) which remained tectonically active until the Pliocene for most of its parts (Sanders et al., 1999). Since the Pliocene it behaved as a tectonically inac- 


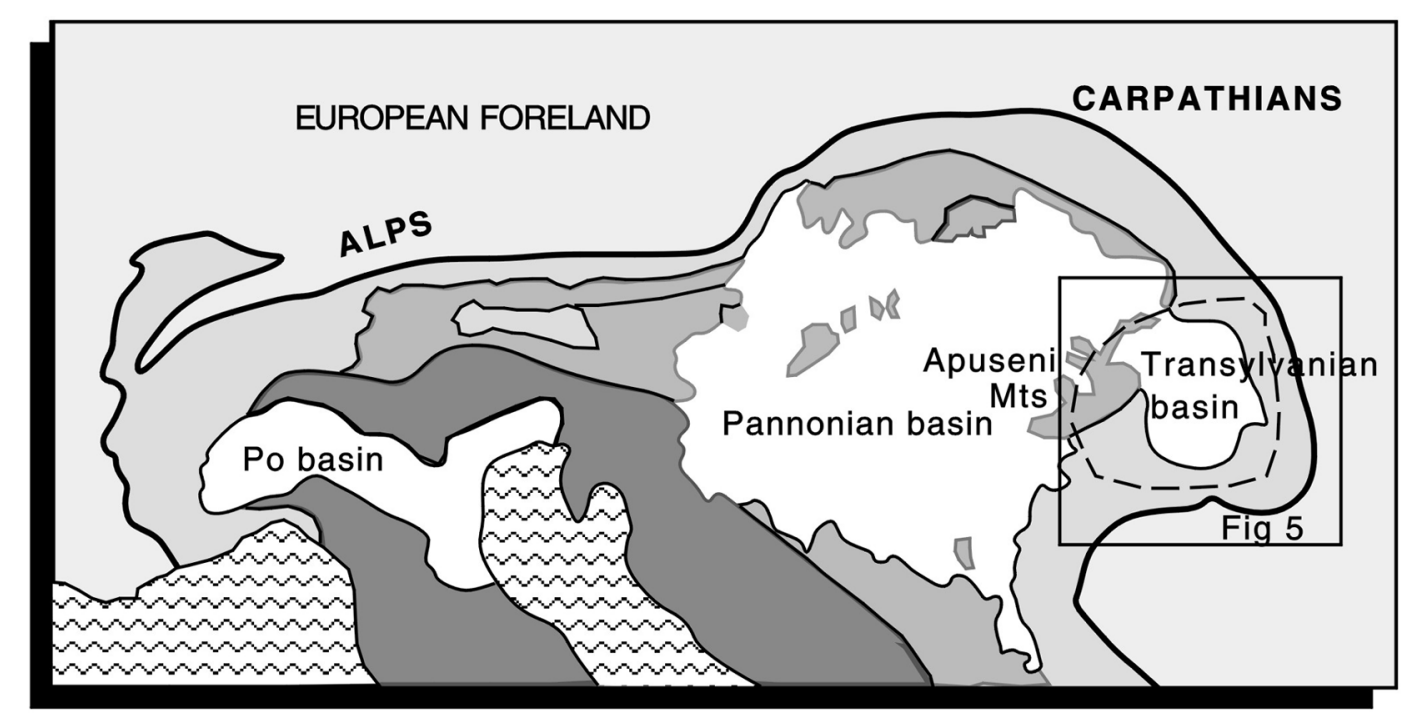

Fig. 1. Tectonic overview over the Alpine-Carpathian orocline (grey). Molasse basins (white) occupy the intra Carpathian region. Dark grey areas represent allochtonous material with respect to the European foreland. Outline shows Fig. 5. Dashed line indicates outline Transylvanian lithosphere block.

tive mountain belt which has been gradually destructed by erosion (Sanders, 1998; Sanders et al., 1999). The Apuseni mountains on the other hand, have a tectonically ambiguous Neogene record (Huismans, 1999; Bleahu et al., 1981; Sanders, 1998;). In this paper we will study the relationship between the evolution of the Transylvanian Basin and its surrounding mountain belts in both a qualitative and a quantitative way.

\section{The Transylvanian basin}

The Transylvanian basin is a semi-circular basin of approximately $150 \mathrm{~km}$ wide and $200 \mathrm{~km}$ long (Fig. 1). It consists of a mostly concordant series of molasse sediments deposited from Mid Miocene to Pliocene (17-5 Ma) (e.g. Koch, 1900) with a typical thickness of $2.5 \mathrm{~km}$ and a maximum thickness of just over $4 \mathrm{~km}$. The base of the basin is defined by a thick volcanic tuff horizon, the "Dej tuff" which overlies an unconformity of regional importance (Ciupagea et al., 1970) (see Fig. 3). This paper is mainly concerned with the Post Dej tuff history of the basin.

The Transylvanian molasse basin is underlain by sediments referred to as "pre-Dej tuff sediments" (or often referred as "pre-salt"). These sediments were deposited from Late Cretaceous to Mid Miocene and are characterised by strong lateral and vertical stratigraphic variations (Fig. 3), indicating that deposition of these sediments occurred in different tectogenetic environments of alternatively local and regional importance (Nagymarosi and Baldi-Beke, 1993; Ciupagea et al., 1970; Huismans et al., 1997; De Broucker et al., 1998). The pre-Dej tuff deposits in turn are separated by an unconformity from underlying intensely deformed Mesozoic sediments and crystalline rocks referred to as "folded basement" (Ciupagea et al., 1970; Fig. 3).

The basin is underlain by the intra Carpathian lithosphere which, in Romania, is at present formed by a semi autonomous block which I refer to as the "Transylvanian block". The autonomy of the Transylvanian block within the intra Carpathian realm is based on geophysical and morphological properties. The most obvious feature of the Transylvanian block is its general high mean elevation compared to surrounding areas. The mean elevation of the Pannonian basin for example is close to sealevel, whereas the lowest mean elevation of the Transylvanian block is around $400 \mathrm{~m}$. The boundary between the high elevated Transylvanian block and the low Pannonian region is formed by the Apuseni mountains. It coincides with a decrease in crustal and lithosphere thickness (respectively from $35 \mathrm{~km}$ to $25 \mathrm{~km}$ and from 120 to $60 \mathrm{~km}$ ) and an increase in the surface heat flow from $40 \mathrm{~mW} / \mathrm{m}^{2}$ in the centre of the Transylvanian basin to more then $100 \mathrm{~mW} / \mathrm{m}^{2}$ in the centre of the Pannonian basin. (Pospisil and Vass, 1984; Horvath, 1993; Dövenyi and Horvath, 1988; Babuska and Plomerova, 1988; Veliciu, 1987). These properties strongly suggest that, based on the above described observations, the Transylvanian block can be considered as a relative competent lithospheric block (Lankreyer et al., 1997) within the weak intra Carpathian realm (Lankreyer et al., 1997; Lankreyer, 1998; Sachsenhofer et al., 1996). Based on the thermal and tectonical history as depicted in Sanders et al. (1999b), and Sanders (1998) it is most likely that the present day situation is representative for the Neogene period. The Transylvanian molasse basin thus formed on top of a cool and moderately thick lithosphere. 

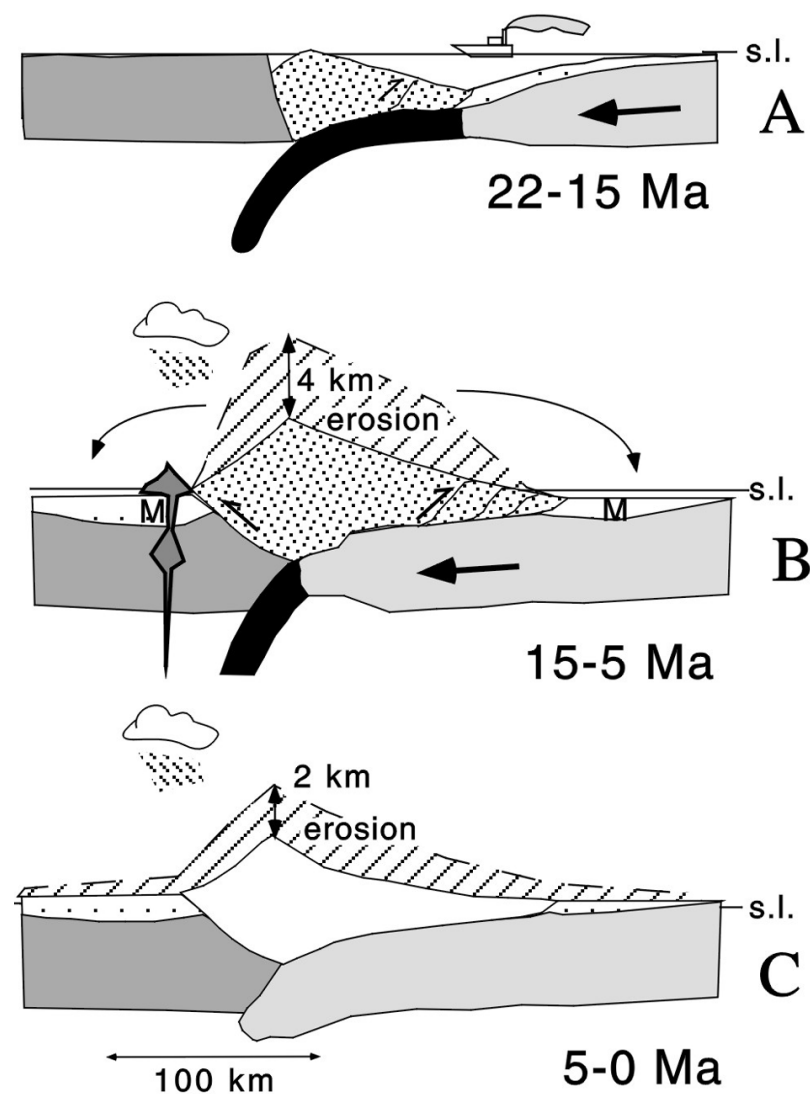

Fig. 2. Three step evolution of the East Carpathians during the Neogene (after Sanders et al., 1999): (A) (25-15 Ma) active but non eroding wedge; (B) (15-5 Ma) Underthrusting of the European continental foreland initiates structural reorganisation and uplift of the wedge. Constructive wedge is under influence of erosion and thrusted over the foreland basins which are coevally subsiding; (C) destructive inactive wedge; general isostatic uplift of the region (note sea level marker). Dark and light gray areas are allochtonous and European lithosphere plates, respectively; black areas are oceanic lithosphere. Close stippled areas are (doubly vergent) wedge; stippled areas (M) are foreland molasse basins.

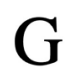

G
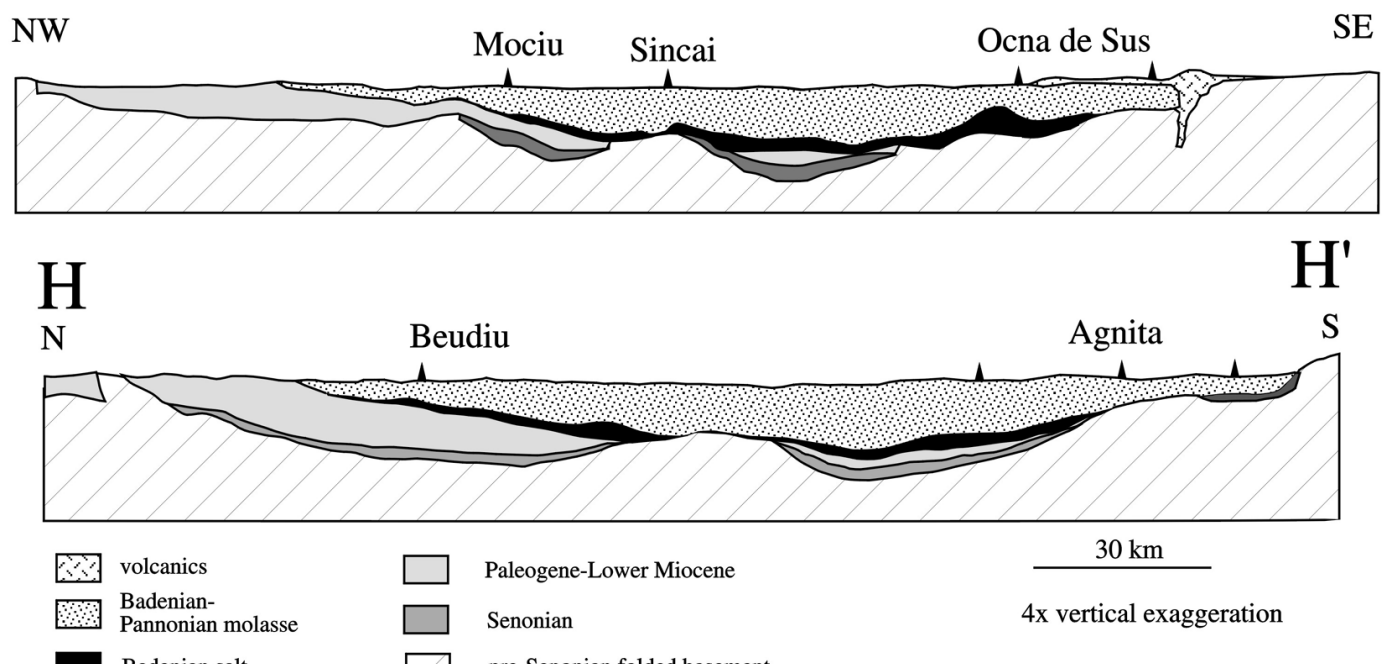

$30 \mathrm{~km}$

$4 \mathrm{x}$ vertical exaggeration

Badenian salt

pre-Senonian folded basement

Fig. 3. Profiles showing the Transylvanian molasse basin and its substratum (after Ciupagea et al., 1970). For location see Fig. 5. 


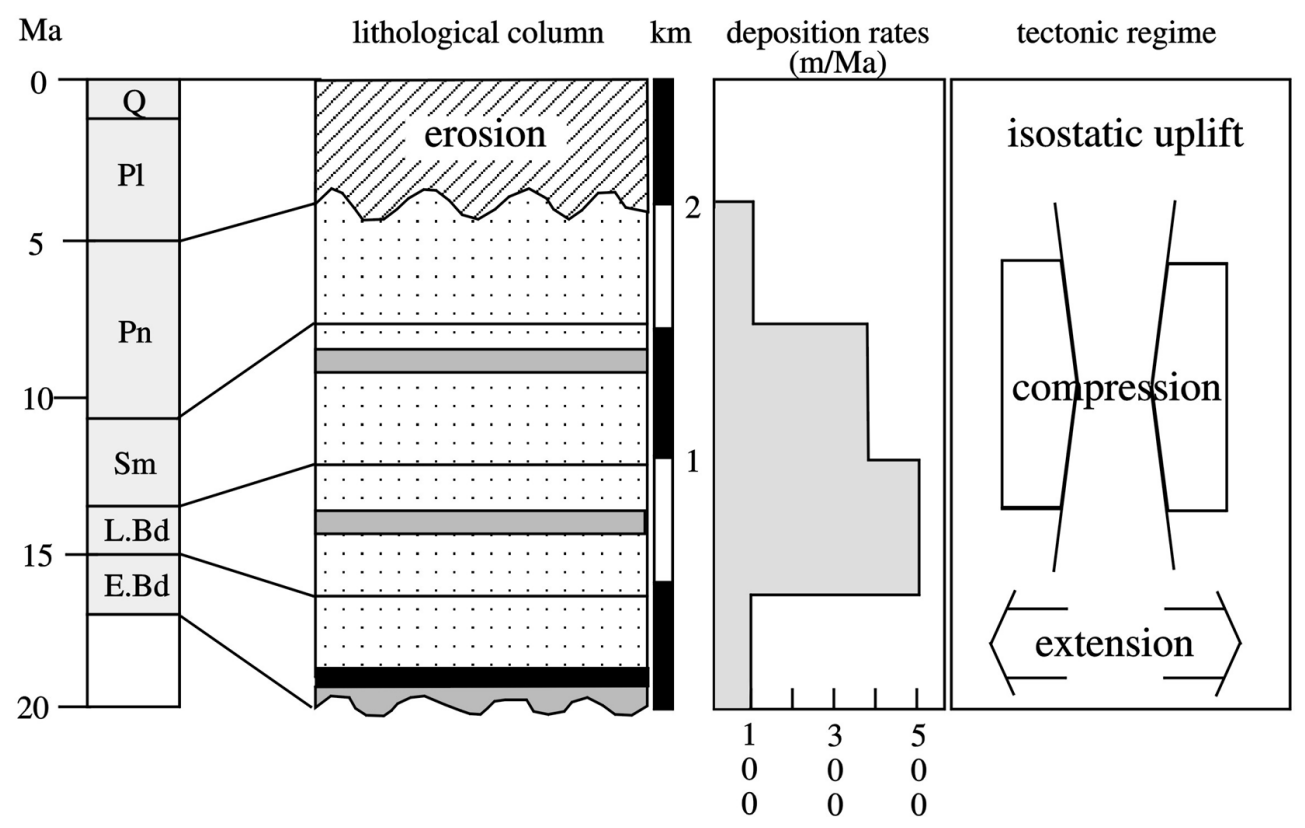

Fig. 4. Schematic representation of the Transylvanian basin deposits. E.Bd; L.Bd; Sm; Pn; Pl; and Q denote Early and Late Badenian, Sarmatian, Pannonian, Pliocene and Quaternary respectively. Column: grey = tuff layers; black = salt; stippled = molasse; vertical scalebar in segments of $500 \mathrm{~m}$. Mean deposition rates are in m/Ma (After Cranganu and Deming, 1996).

\subsection{The Neogene molasse basin}

The Early Badenian (17-15 Ma) rhyolitic Dej tuff is overlain by a salt layer of typical $300 \mathrm{~m}$ thick (Cranganu and Deming, 1996), intercalated with basal clastic conglomerates (Ciupagea et al., 1970) and overlain by a uniform series of mainly siliciclastic molasse sediments (Fig. 4). The molasse sediments are made up of immature lithic sand, conglomerate, clay and marl. The coarser and badly sorted deposits generally occur at the rim of the basin while the fine grained sediments prevail in the centre of the basin (Marunteanu, 1998; Marinescu et al., 1994). The entire series of molasse sediments is intercalated with volcanic tuff layers of predominantly andesitic signature (Ciupagea et al., 1970). Sedimentation of the Miocene molasse took place in a deep to shallow marine environment during the Badenian and Sarmatian but was gradually changing to shallow brackish conditions during the Pannonian (Ciupagea et al., 1970; Dercourt et al., 1986; Steininger et al., 1988; Marunteanu, 1998).

Badenian (17-13 Ma) deposits are on average $400 \mathrm{~m}$ thick but reach maximum thickness of $1500 \mathrm{~m}$ especially in the centre of the basin (Stefanescu, 1985; Cranganu and Deming, 1996). During the Late Badenian sedimentation rates drastically increase from approximately $100 \mathrm{~m} / \mathrm{Ma}$ to $500 \mathrm{~m} / \mathrm{Ma}$ (Cranganu and Deming, 1996).

On top of the Badenian deposits lies a concordant series of thick mostly undisturbed Sarmatian (13-11 Ma) molasse sediments that are on average $600 \mathrm{~m}$ thick but locally reach thicknesses up to $1500 \mathrm{~m}$. They are deposited in a relatively short time period and mark a period of high subsidence and sedimentation rates $(350 \mathrm{~m} / \mathrm{Ma})$. Deposition of molasse sed- iments continues in the Pannonian (11-5 Ma) at lower rates (approximately $100 \mathrm{~m} / \mathrm{Ma}$ ), locally interrupted by an unconformity between the Sarmatian and Pannonian deposits. Pannonian deposits are typically $500 \mathrm{~m}$ thick.

Since the Pontian (7-5 Ma), no basin deposits are preserved and the basin was presumably under the influence of erosion until the present day (Marunteaunu, 1998; Sandulescu, 1988). Today the sediments reach an average elevation of $400 \mathrm{~m}$ above sealevel throughout the basin. The strata are gently tilted towards the centre of the basin but strongly tilted at the extreme rim where they reach peak elevations up to $800 \mathrm{~m}$. In the north tilting is less extreme and occurs on a more regional scale. Here, no Pannonian sediments are present (Sandulescu et al., 1978), either due to non deposition or more likely due to Pliocene erosion.

\section{Relations between mountains and basin}

The Transylvanian basin is presently at all sides surrounded by mountainous regions. Ciupagea et al. (1970) and Sandulescu (1988) have proposed that the present day configuration originates from the Miocene and was responsible for the restricted marine environment in which the sediments were deposited (Marinescu et al., 1981).

Apatite fission track studies (Sanders, 1998; Sanders et al., 1999, 1999b; Andriessen, 1995) supports this hypothesis. It suggests that the configuration was well established during the Late Badenian-Sarmatian (15-11 Ma) due to the creation of a topgraphically high Carpathian mountain range and Apuseni mountains. Early Badenian molasse deposits are presently found at high altitudes in the mountainous re- 
gions (e.g. Codarcea et al., 1968; Gh. Popescu, pers. comm., 1997) indicating that the areal extend of the Early Badenian basin was larger than the present day outline of the Transylvanian basin. It also indicates that substantial vertical movements (>1000 m) must have taken place after the Early Badenian. Evidence for pre Late Badenian mountain ranges could not be supported by Apatite Fission Track Thermochronology (AFTT). In this paper it will be suggested that strong relationships exist between the mountain ranges and the basin forming an integrated and causally related system:

i) The eroding mountains provide the clastic material deposited as molasse sediments in the basin (e.g. Schlunegger et al., 1997). The load of the deposited sediments enhances the subsidence of the basin floor, creating extra accomodation space.

ii) The mountain ranges form barriers for sediment and water exchange with neighbouring basins. The Miocene uplift of the Carpathian orocline for example blocked the seaway between the Central and Eastern Paratethys. The Apuseni mountains, on the other hand, formed a threshold for sediment transport to or from the Pannonian basin. Sediments deposited in the Transylvanian basin thus remained in place and could not easily be transported over large distances to neighbouring basins. Paleontological arguments support the idea of limited exchange of water especially with the warm waters of the Eastern Paratethys and the Tethys to the south and east (e.g. Marinescu et al., 1994).

iii) The topographic load of a growing mountain suppresses the lithosphere plate on which it rests. Due to the elastic strength of lithosphere plates this creates tectonic subsidence and accommodation space for sediment deposits in front of a mountain belt (termed "foredeep") (e.g. Beaumont, 1981; Zoetemeyer, 1993). The same principle is applicable to the retro-foreland plate in the case of doubly vergent orogenic wedges (e.g. Johnson and Beaumont, 1995; Willet et al., 1993; Jordan, 1995).

Data presented by Sanders et al. (1999) and Sanders (1998) suggest that the East and South Carpathians are indeed doubly vergent orogenic wedges where a significant part of the orogen is thrust over the retro foreland (Transylvanian block). Moreover, AFTT data suggest that the topographic load of these orogens drastically increased during the Late Badenian-Sarmatian. Thus in time the uplift and erosion of the mountain ranges closely correspond to rapid subsidence and accelerated sedimentation rates in the Transylvanian molasse basin. This view is supported by sedimentological lithofacies evidence and sediment transport directions (Marunteanu, 1998; Marinescu et al., 1994). Finally palynological analysis on Miocene basin sediments indicate an explosive growth of high altitude vegetation during the Sarmatian confirming the creation of high topography in the surrounding mountain ranges (Marinescu et al., 1994).

\section{Structural control on basin development}

The structural control on the evolution of the Transylvanian basin has been poorly-defined until new insights came from paleo stress measurements (Huismans et al., 1997, 2002) and new seismic data (Ciulavu, 1999, and De Broucker et al., 1998). From a tectonic point of view the Transylvanian basin forms the transition zone between the compressional Carpathian orogen in the east and south and the extensional Pannonian basin in the west. The compressional and extensional regimes in these regions were simultaneously active during the Mid- and Late Miocene (Horvath, 1993; Csontos, 1995; Royden, 1988, Huismans et al., 2001).

Based on measurements on large scale structures and paleostress analysis (Huismans et al., 1997, 2002; Ciulavu and Bertotti, 1994; Gyorfi and Csontos, 1994) two distinct tectonic regimes are distinguished in the evolution of the Transylvanian basin. An early extensional phase is recognised in Badenian sediments, and a late compressional phase in the Sarmatian and younger sediments.

Small scale structures indicate roughly east-west extension throughout the Transylvanian region during the Badenian. Note that, unlike the Pannonian basin, large scale extensional structures have never been observed. In time the extensional phase of the Pannonian basin and the Transylvanian basin coincide well however, both starting in the Early Badenian (Csontos, 1995; Tari et al., 1992; Huismans; 1999; Gh. Popescu, pers. comm., 1997).

In Badenian and younger sediments extensional structures are overprinted by younger compressional structures also occurring in the Sarmatian and to a minor extend in the Pannonian molasse deposits. The often large scale compressional structures indicate a regional east-west compression (Huismans et al., 1997) and are most intense at the eastern and western rim of the Transylvanian basin where the strata are tilted, folded and fractured. Offsets along reverse- and thrustfaults is observed to be several meters in outcrops. On seismic sections an off-set of up to $1 \mathrm{~km}$ is observed in the eastern part of the Transylvanian basin (De Broucker, pers. comm.; Ciulavu, 1999). In the same area a series of west vergent thrusts is recognised. The orientation of salt domes is consistent with E-W compression. The onset of the compressional regime is most likely Late Badenian-Sarmatian (15-11 Ma) (Sanders et al., 1999). A third phase from Pliocene to Quaternary (5-0 Ma) marks the epeirogenetic uplift and erosion of the basin.

\section{Mass balance}

The restricted nature of the Transylvanian basin allows us to define a closed system for the erosion-deposition cycle. Based on the AFTT data (Sanders et al., 1999; Sanders, 1998), a mass balance can be calculated between the material eroded from the mountains on one hand and the material deposited in the basin reservoir on the other. If no material has been lost or gained the two sides of the mass balance 


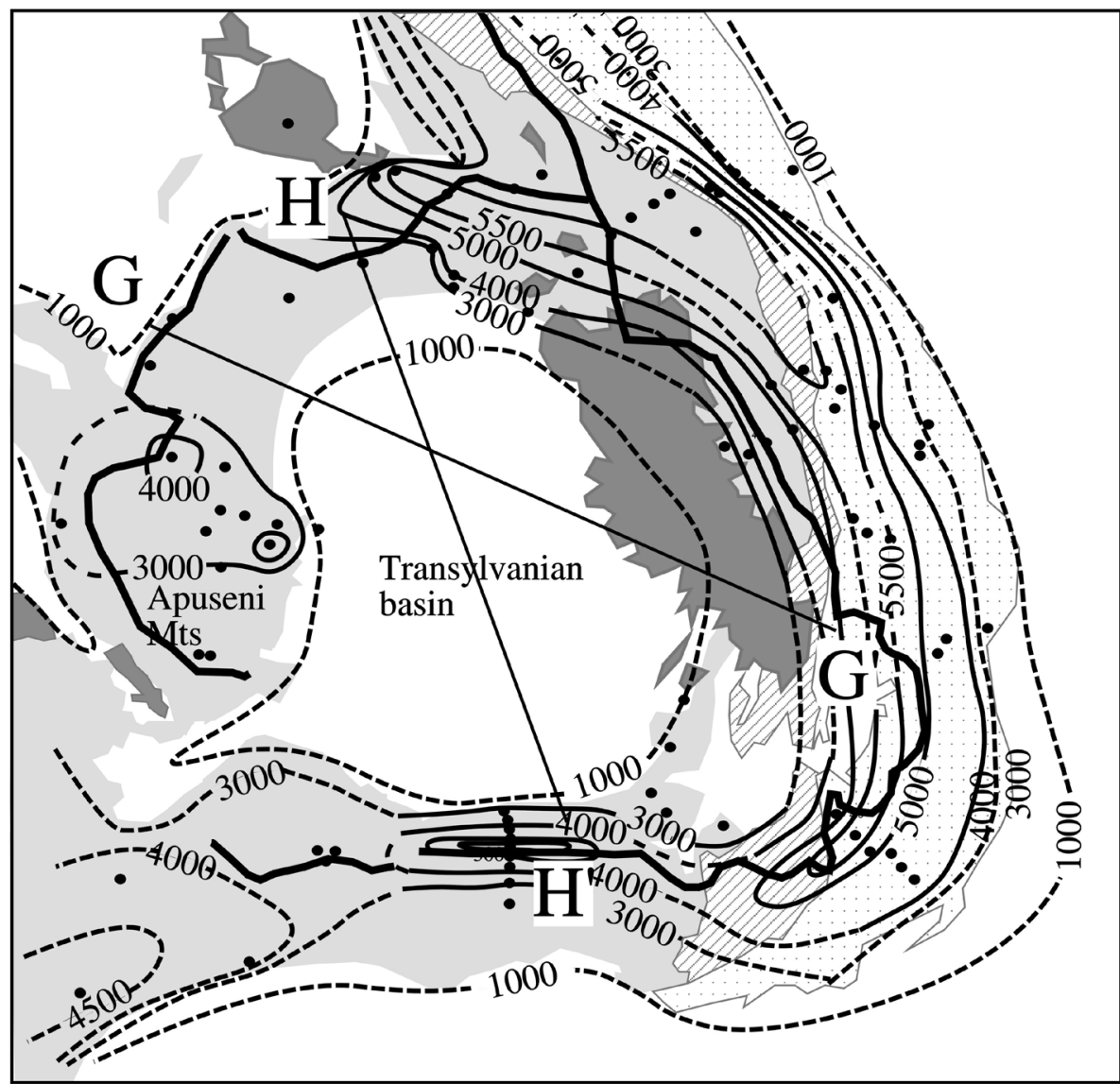

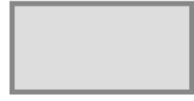

Pre- Mid Miocene sediments and basement

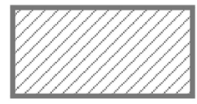

Outer Dacides (Flysch belt)

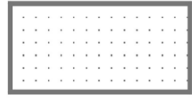

Moldavides (flysch belt)

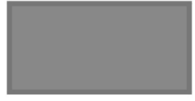

Neogene volcanics

Fig. 5. Simplified map showing iso-erosion lines (in meters) based on AFTT (Sanders et al., 1999; Sanders, 1998). Dashed lines indicate poor control. Black dots are locations of AFTT samples. G and H are labelled profile lines of Fig. 3. Thick black line indicates main drainage divide.

should yield equal amounts. As a first approach we will calculate a volume balance for the period from Early Badenian to recent (17-0 Ma) covering the entire deposition and erosion history of the basin and mountains respectively. It will afterwards be modified for the period for which we can define a closed erosion-deposition system (15-5 Ma) and is consequently converted to a mass balance. After weathering and erosion material was transported from the mountains to depositional reservoirs by transport media, mostly river systems. The main drainage divide of a mountain range therefore primarily determines whether eroded material is transported to the foreland- or to the retro-foreland basin (Fig. 5).

The total volume of the molasse sediments of the Transylvanian basin is estimated using a digitising computer program. The isopachs of the Badenian Dej tuff are modified after Mahel (1973) and mark the base of the basin volume. The present day topographic crests of the basin deposits is taken as the top of the basin volume. The total volume calculated for the Transylvanian basin amounts to $45 \times 10^{3} \mathrm{~km}^{3}$.

The same technique is used to calculate the volume of the material eroded from the mountains using the interpolated "isopach" lines of removed overburden (Fig. 5) as derived from AFTT (Sanders et al., 1999; Sanders, 1998). For the mass balance we only consider the volume eroded from the flank of the mountain range that faces the Transylvanian basin, since this material is transported to the Transylvanian basin (Fig. 5). Furthermore the rim of the basin is taken to be a constant non erosion-non deposition interface. The total volume $(\mathrm{V})$ of material eroded from the mountains is then calculated to be $43 \times 10^{3} \mathrm{~km}^{3}$. Assuming uniform densities (r) of $2.3 \mathrm{~g} / \mathrm{cm}^{3}$ for both eroded and deposited material and using the following equation:

$V r=m$ 
reveals the mass (m) of the basin sediments to be $104 \times 10^{15} \mathrm{~kg}$ and the mass of the eroded material in the mountains to be $99 \times 10^{15} \mathrm{~kg}$. Uniform densities are assumed because it is unknown what lithology the eroded material was made of. However, a closed system can only be defined from Late Badenian to Pliocene (15-5 Ma). Any material deposited before and eroded after this period cannot be incorporated in the mass balance calculation and must be corrected for.

i) Early Badenian (17-15 Ma) sediments have been deposited over a larger area then the present day outline of the basin and the provenance of these sediments is unknown. According to AFTT the Carpathian and Apuseni mountains were not eroding (Sanders et al., 1999; Sanders, 1998) during this period. The sediment volume (a uniform layer of approximately $500 \mathrm{~m}$ thick (Cranganu and Deming, 1996) is extracted from the total basin volume.

ii) From the Pliocene to recent the basin presumably did not store erosion products shed from the orogens. The material eroded in the orogens during the Pliocene was deposited elsewhere and must be considered as a nett loss of mass and subtracted from the balance on the "orogen side". Pliocene to recent erosion in the East Carpathians is estimated to be $1.5( \pm 1) \mathrm{km}$ over the core of the orogen (Sanders et al., 1999) which equals to approximately $25 \%$ of the total erosion. A similar Pliocene erosion component of $25 \%$ is assumed for the Apuseni mountains and the South Carpathians $(1 \mathrm{~km}$ of erosion).

Material eroded in the south western Bend Zone of the East Carpathians is not incorporated in the mass balance since erosion took predominantly place in the period from Pliocene-recent (5-0 Ma) (Sanders et al., 1999). The total mass eroded from the mountains during the period from Late Badenian to Pliocene (15-5 Ma) is finally determined at 75 $10^{15} \mathrm{~kg}$.

The Transylvanian basin itself was also subject to erosion during the Pliocene and Quaternary. AFTT on drill holes, sonic analysis (De Broucker, pers. communication) and unconsolidated Pannonian sediments indicate no more then a few hundred meters of erosion. A uniform amount of erosion of the basin sediments is estimated at $0.5 \mathrm{~km}$ and must be added to the mass of the basin. This material namely represents erosion products from the mountains that were originally deposited in the basin during the Pannonian. Finally the tuffaceous layers that are intercalated between the clastic molasse deposits form a volume of material that has no origin in mountain erosion and must be regarded as foreign material. Tuffaceous material is estimated to be $10 \%$ of the total basin mass (Ciupagea et al., 1970).

Taking all modifications for a closed erosion-deposition system into account the total mass of the basin sediments amounts to $93 \times 10^{15} \mathrm{~kg}$ which closely corresponds to the $75 \times 10^{15} \mathrm{~kg}$ of mass eroded from the mountains from Late
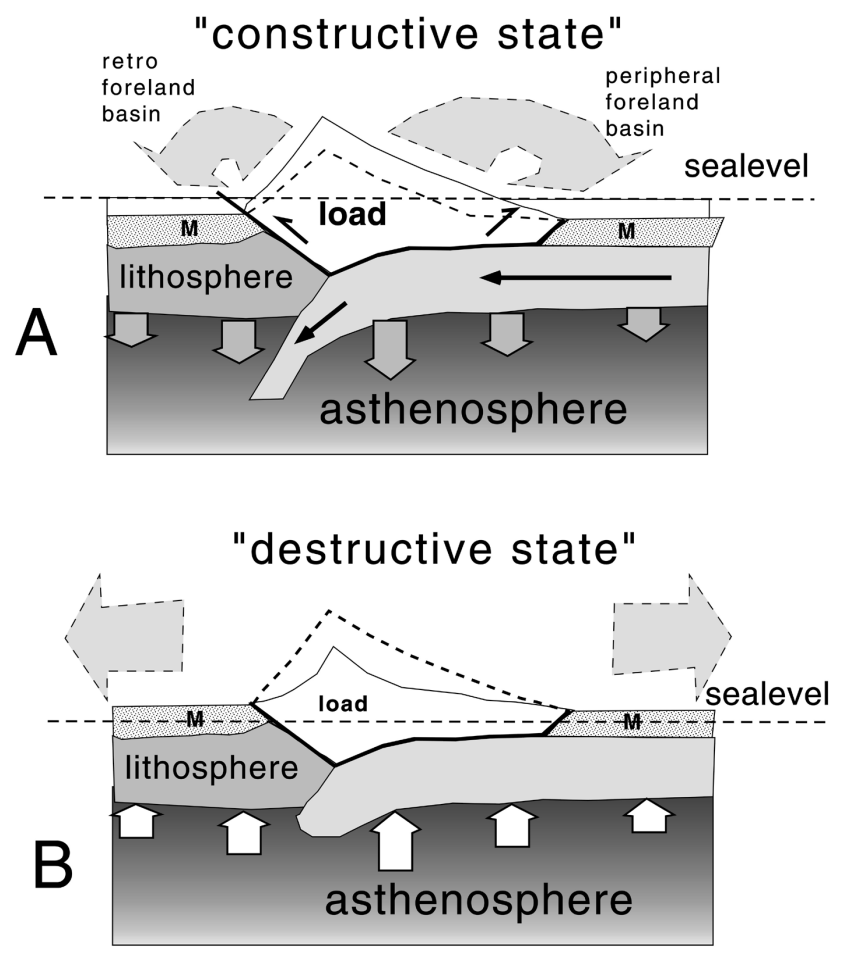

Fig. 6. Effect of wedge growth on regional vertical movements (After Sanders, 1998). Dark and light grey are respectively allochtonous and European lithosphere plates "floating" on asthenosphere. Stippled (M) are foreland molasse basins. Grey arrows illustrate erosion transport. Black and white arrows are downward and upward movement of lithosphere plates due to isostacy. (A) shows constructive wedge causing strong differential vertical movements in the region. General isostatic subsidence is indicated by sea level marker. (B) shows destructive state wedge causing general isostatic uplift of the region (note sea level marker). Stippled wedge surface is at $\mathrm{t}_{1}$, continuous wedge surface at $\mathrm{t}_{2}$.

Badenian to Pliocene. The mass balance can only be used in a first order approximation since its precision relies mostly on the estimated paleo-geothermal gradient, which is relatively well defined in this case $\left(20^{\circ} \mathrm{C} / \mathrm{km}\right)$ (Sanders et al., 1999). On the other hand, when the mass balance fits and is well defined by geological information, as is the case for the Transylvanian basin, it forms a good control whether the erosion estimates based on thermo-chronological techniques are realistic.

\section{Tectonic concept and numerical simulation}

A mechanical relationship between the evolution of the East Carpathian orogen and the subsidence of the Transylvanian basin was suggested in a qualitative way by Sanders et al. (1999) and in more general terms by Peper et al. (1995). The partial thrusting of the Carpathian orogenic wedge over the Transylvanian block has a predictable influence on the vertical movements in the retro foreland (see Fig. 6). The concept will be numerically tested for its physical probability 


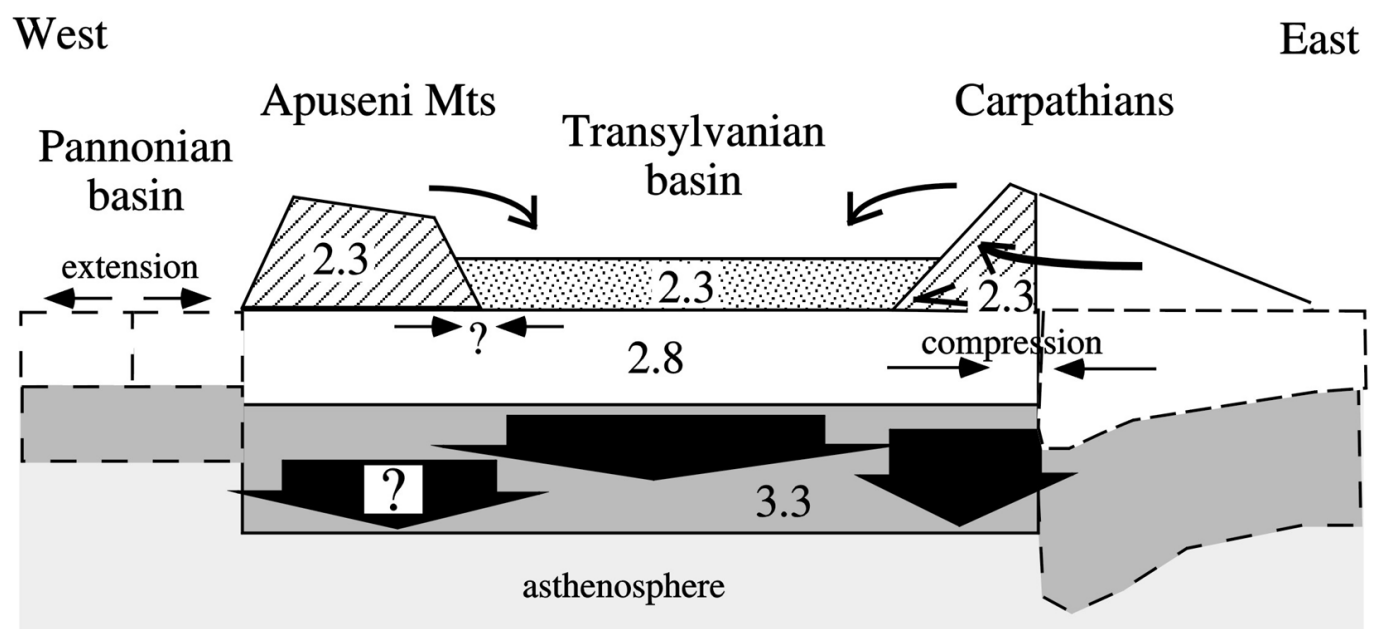

Fig. 7. Cartoon illustrating tectonic concept for the numerical modelling exercise of the Transylvanian basin subsidence. See text for explanation. Large (black) arrows indicate load. Small curved arrows indicate mass transport. Small straight arrows indicate compressionalor extensional regime. White is lithospheric crust, dark grey lithospheric mantle and light grey asthenosphere. Numbers indicate density of material $\left(\mathrm{g} / \mathrm{cm}^{3}\right)$

in a simplified form using a three dimensional isostatic and flexural model.

Figure 7 shows the simplified conceptual model (in 2D) used for the calculations. The Transylvanian lithosphere is represented by a horizontal plate. A significant part of the mass of the orogenic wedges of the East and South Carpathians is thrusted over the Transylvanian lithosphere. The weight of the mountains suppresses the lithosphere plate creating a retro-foredeep (the Transylvanian basin). The subsidence of the foredeep is enhanced by the infill with erosion material derived from the orogens. No mass is lost due to erosional processes but only redistributed over short distances from the mountains to the basin.

The tectonic role of the Apuseni mountains on the other hand is ambiguous during the Miocene. It remains unclear whether the uplift of the Apuseni mountains during the Neogene is related to compressional thickening (like the Carpathians) or to block (flank) uplift under influence of the extensional regime in the Pannonian basin (e.g. Huismans et al., 1998). Compressional thickening of the Apuseni mountains is probably accompanied by thrusting over the Transylvanian basin. Arguments are the tilting, folding and thrusting of basin sediments on the border with the Apuseni mountains (see also Huismans et al., 1997, 2002). This concept was already suggested by Pauca (in Ciupagea et al., 1970) and would create a load on the Transylvanian plate in the west.

Alternatively, the uplift of the Apuseni mountains might be due to extensional tectonics in the Pannonian basin with a flank uplift as the main process for the creation of the mountainous topography (Sanders, 1998). Flank uplift does not create a load on the Transylvanian plate since the uplift is due to an isostatic-flexural response (e.g. Van der Beek et al., 1994). The two alternatives ("compressional scenario" and "flank uplift scenario") are tested in the numerical simulation model (see below). A combination of both processes is obviously possible in reality (Huismans et al., 2001, 2002).

We explicitly only consider the influence of tectonic loading processes and mass fluxes caused by surface processes on an elastic uniform lithosphere which floats isostatically on viscous asthenosphere. All other processes that might lead to vertical movements are assumed constant. The exercise explicitly answers the question to what extend the Transylvanian basin can be considered as a retro-foreland basin (e.g. DeCelles and Giles, 1996; Jordan, 1995; Cobbold et al., 1993). For detailed information on the model specifications one is referred toVan Wees et al. (1996).

The Transylvanian plate is in the simulation represented by a uniform horizontal lithosphere plate (Fig. 7) with an effective elastic thickness (EET) of $20 \mathrm{~km}$, which fits the present day geophysical data (Lankreyer et al., 1997). The top of the plate is at sealevel. A moderately thick crust of $35 \mathrm{~km}$ thick and a total lithosphere thickness of $120 \mathrm{~km}$ is used in the simulation based on data presented by Dövenyi and Horvath (1988) and Babuska and Plomerova (1987). The density of the model crust and mantle are $2.8 \mathrm{~g} / \mathrm{cm}^{3}$ and $3.3 \mathrm{~g} / \mathrm{cm}^{3}$ respectively. The outline of the Transylvanian lithosphere plate is relatively well defined in three dimensions (Fig. 1). The western border is mainly constrained by geophysical- and structural arguments and the topography (Sanders, 1998) suggesting an extensional boundary west of the Apuseni Mountains. Its southern and eastern plate margin are defined by the subduction zone under the Carpathians and are taken from published geological sections (Stefanescu, 1985). In the north the plate margin is taken to coincide with the Dargoss-Voda fault which is a large strike slip fault. All plate boundaries are assumed weak (e.g. Matenco et al., 1998; Lankreyer et al., 1997). As a very simplified approach the Transylvanian plate can be viewed as a loosely floating elastic plate, loaded at its rims with mountains and filled in the centre with sediments (Fig. 7). 

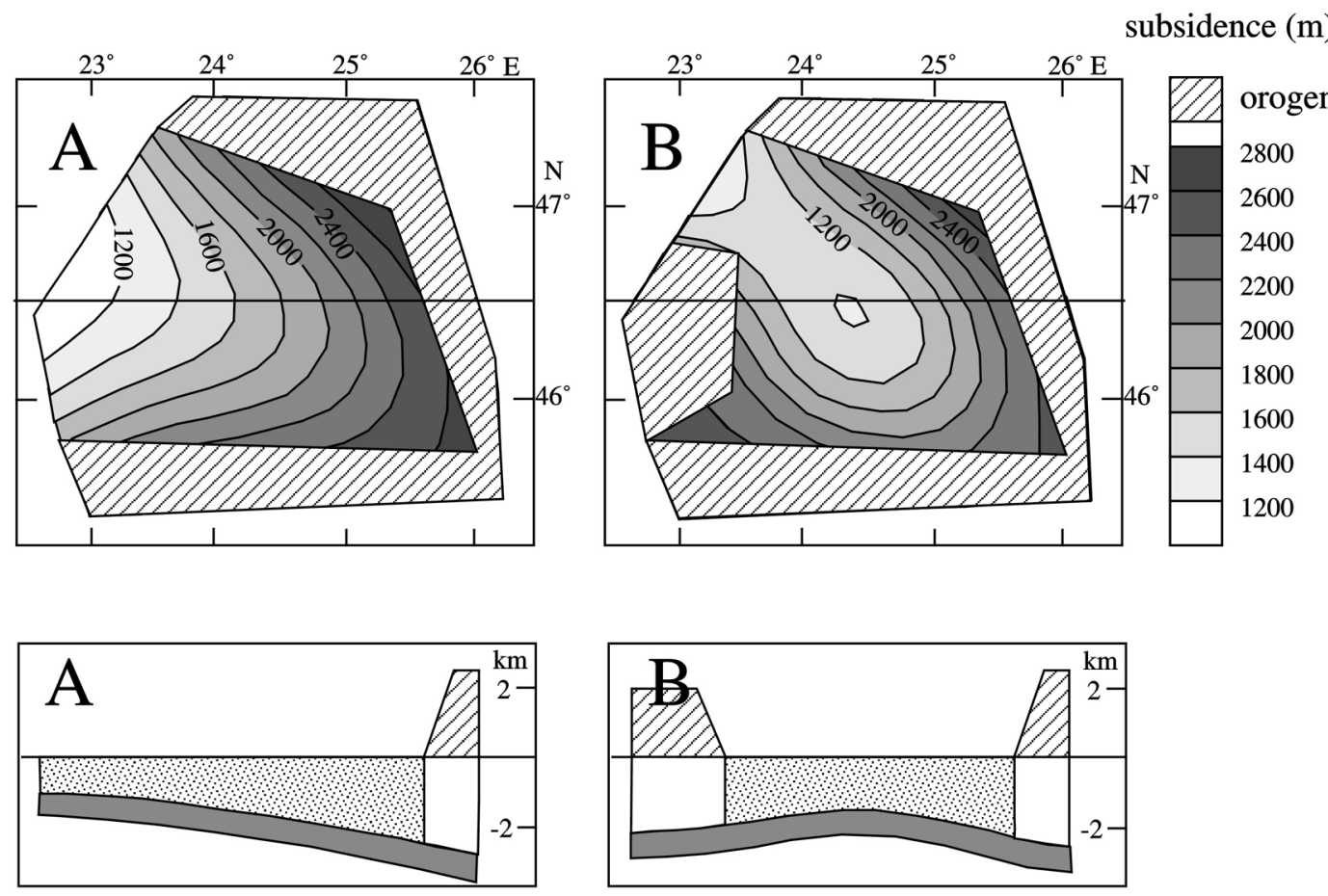

Fig. 8. Result of numerical simulation for the loading phase (15-5 Ma) (see text). Upper panels give plan view: outline figure signifies Transylvanian plate; grey scale indicates subsidence of basin floor with respect to starting configuration; hatched represents mountain ranges. Lower panels show east-west cross section along the centre of the plate. Dark grey is basin floor; stippled are molasse sediments. Left panels show result without load of Apuseni mountains; right panels with Apuseni mountains of $2000 \mathrm{~m}$ high.

\subsection{Phase I: Tectonic loading (15-5 Ma)}

The first run simulates the growth of the orogen (constructive state) and the filling of the Transylvanian basin with molasse sediments during the Late Badenian-Pannonian (15-5 Ma). The horizontal lithosphere plate is instantaneously loaded with the orogens until the mountains reach a pre-defined elevation. For the East and South Carpathians a maximal mean elevation of $2500 \mathrm{~m}$ a.s.l. is taken (see discussion). The thus created retro-foredeep is filled with sediments to sealevel. Both orogen and sediments have a uniform density of $2.3 \mathrm{~g} / \mathrm{cm}^{3}$ in the model (Fig. 7).

Figure 8a illustrates the basement subsidence that is predicted when the topographic load of the Apuseni mountains is ignored (flank uplift scenario). The basin has a marked asymmetric form deepening to the Carpathians. In Fig. 8b, the load of the Apuseni mountains is incorporated (compressional scenario) using a maximum elevation of $2000 \mathrm{~m}$ a.s.l. Most subsidence occurs in the direct vicinity of the mountain loads and a bowl shaped basin forms with a flexural bulge in the centre. In both scenarios basement subsidence approximates $2 \mathrm{~km}$ due to the combined load of orogen and sediments. The magnitude of model B subsidence is in fairly good agreement with observations. Syn-compressional Late Badenian to Pannonian deposits are typically $1500-2500 \mathrm{~m}$ thick (Cranganu and Deming, 1996).

\subsection{Phase II: Erosional unloading (5-0 Ma)}

In the Pliocene the basin no longer subsides presumably because the orogen was in a destructive state (Sanders et al., 1999). Erosion continued and mass was transported out of the area causing regional isostatic uplift. The Pliocene erosional unloading period is modelled by taking the final result of Fig. $8 \mathrm{~b}$ as starting configuration. The maximum elevation of the mountains is fixed at $1000 \mathrm{~m}$. The maximum basin surface elevation is set at $300 \mathrm{~m}$ and the extra space is filled with sediments (Fig. 9a). This simulates the present day situation which is assumed to be an isostatic equilibrium configuration. The model then calculates the coinciding depth of the basement level for the fixed conditions. The results are depicted in Fig. 9a. The contours in the plan view are the amount of erosion predicted to achieve the isostatic equilibrium configuration. Most isostatic rebound takes place in the mountains which results in upwarping of the strata along the basin rim. As a result the initial dome in the centre of the basin (Figs. 8b and 9a) is more or less annihilated.

The amounts of Pliocene erosion predicted by the model are close to the erosion estimates that were independently constrained by AFTT (Sanders et al., 1999; Sanders, 1998). In Fig. $9 \mathrm{~b}$ the same boundary conditions are applied with the exception that the basin surface elevation was set at an altitude of $500 \mathrm{~m}$. Figure $9 \mathrm{~b}$ shows that for this configuration no erosion is predicted in the centre of the basin but subsidence instead, illustrating the impossibility of this scenario. The 

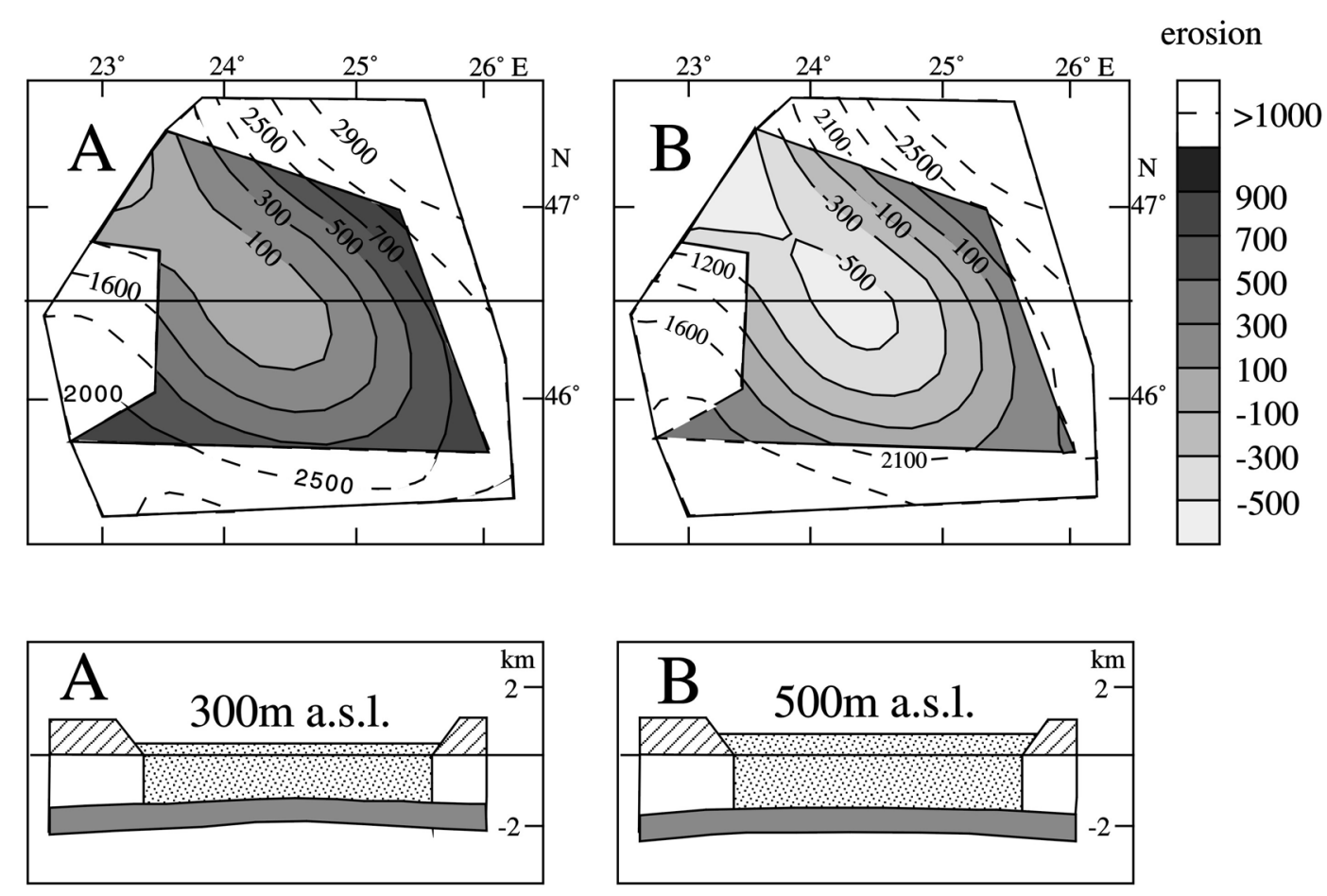

Fig. 9. Result of numerical simulation of erosional unloading phase (5-0 Ma). Left panels with Transylvanian basin surface at $300 \mathrm{~m}$ elevation, right panels at $500 \mathrm{~m}$. Grey scale indicates amount of erosion predicted in the basin; white the amount of erosion predicted in the mountainous areas. Lower panels show the final basin and mountain configuration.

created topographic load of the basin itself is too high and subsidence of the basement level is predicted. In other words the basin has to increase in thickness to achieve the fixed elevation of $500 \mathrm{~m}$ above sealevel. The two simulation runs show that the isostatic basin surface uplift reaches a ceiling between 300 and $500 \mathrm{~m}$ altitude under the defined conditions.

At present the Transylvanian basin has a mean surface elevation of approximately $400 \mathrm{~m}$. Post tectonic erosion of the mountains and the basin are therefore well capable to create most of the observed surface uplift of the Transylvanian basin during the Pliocene and Quaternary. Also the gently basinward tilted strata along the rim of the basin can be explained by the Pliocene isostatic rebound.

\section{Discussion}

The above described compressional loading (Phase I, model B) and erosional unloading scenario from Late Badenian-recent (15-0 Ma) is a likely mechanism to explain most of the subsidence and uplift history of the Transylvanian basin. For Phase I, we prefer the compressional loading scenario. This agrees well with the first order geometry of Neogene sediments in the Transylvanian basin, and with the observed contractional loading structures on the western side of the basin bordering with the Apuseni Mts. (e.g. Huismans et al., 2002). For Phase II, the models suggest that most erosional unloading occurred in the mountain ranges surrounding the Transylvanian basin. The magnitude of uplift and subsidence are within realistic limits and are in agreement with the amounts of erosion observed with AFTT. The proposed scenario fits the structural, sedimentological- and geophysical observations and is considered a valid hypothesis for the tectonic origin of the Transylvanian basin. The concept is most applicable for the Eastern and Southern parts of the basin since the tectonic history of the surrounding mountains is best constrained here.

Two obvious factors like the compaction of sediments (including the basin substratum) and the initial basin geometry (e.g. Dercourt et al., 1986; Marunteanu, 1997) may enhance the subsidence of the basin in reality. No data are available on these parameters but they most likely result in extra accommodation space for sediment deposits resulting in potentially higher subsidence values compared to the modelled results. The modelled subsidence values are therefore minimum estimates.

The paleo elevation of the Carpathian mountains is unknown. The numerical simulation in combination with the AFTT data shows that a $2500 \mathrm{~m}$ high paleo elevation is a realistic estimate. If one compensates for lithology densities the real average paleo elevation was probably just over $2000 \mathrm{~m}$ a.s.l.

The sealevel has been assumed constant for simplicity reasons. In reality global fluctuations in the order of $150 \mathrm{~m}$ are reported during the Neogene (Haq et al., 1987). The vertical movements due to tectonic forces during the BadenianSarmatian and the Pliocene are of a much greater magnitude 
than the eustatic sealevel changes which makes the assumption valid.

Other basin forming mechanisms like extension and backarc spreading require predominantly extensional structures and high thermal heatflows due to a thinning lithosphere, which has not been observed in the Transylvanian basin. Also a thermal relaxation ("thermal sag basin") following an initial extensional period is unlikely because it does not fit with the observed thermal and depositional regime. Postextension deposits are on average three times as thick as synextensional deposits which is unrealistic for thermal subsidence.

Mitrovica et al. (1989) and Gurnis (1992) have suggested an alternative mechanism for basin development on the retro foreland plate. According to their calculations a subducting plate can create disturbances in asthenospheric mantle convection sufficient to initiate subsidence in the overlying lithosphere plate in the order of several $\mathrm{km}$. The basin dimensions they predict are in general agreement with those of the Transylvanian basin. Moreover uplift is predicted after cessation of the subduction process. It is a possible alternative to explain the evolution of the Transylvanian basin but a scenario that is not easily testable in a natural setting.

As with all basins, subsidence need not be explained by a single mechanism. In reality several mechanisms attribute to the total subsidence of a basin with one or two mechanisms dominating. The previous described and modelled compressional mechanism is a likely candidate to dominate the subsidence and uplift history of the Transylvanian basin. The proposed model fits very well with the structural analysis, the regional low thermal heat regime and the tectonic and erosion history of the mountain ranges. Moreover, it can explain the enigmatic present day high surface elevation of the basin.

\section{Conclusions}

The evolution of the Neogene Transylvanian basin is closely related to the evolution of its surrounding mountain belts. Following a phase of extension in the Early Badenian, the basin rapidly subsided under a compressional regime due to the loading of the growing mountain belts and the infill of molasse sediments. From the Pliocene onwards the mountains were in a destructive state and were gradually abrased by erosion. The basin filled up with sediments and was eventually exposed to erosion, leading to a nett mass loss in the region. As a result the basin was subsequently uplifted to $400 \mathrm{~m}$ above sealevel during the Pliocene due to isostatic and flexural rebound.

A mass balance showed that most material eroded from the internal flanks of the mountain ranges during the Late Badenian-Pannonian is preserved in the Transylvanian basin confirming the restricted nature of the basin. Under these conditions a mass balance is a useful tool to check if the erosion history as assessed by thermochronological data is based on realistic assumptions (for example the choice of the paleo- geotherm). In the case of the Transylvanian basin the mass balance fits quite well and confirms the erosion and tectonic history described here.

The numerical model simulates the magnitude of vertical motions that can be expected due to loading and unloading processes. It illustrates the influence of surface processes on the tectonic relation between the retro foreland basin and the mountains. On a large scale it constrains the regional geomorphological evolution of the area through time.

Acknowledgements. We wish to thank Gilles De Broucker (Shell Romania) for the constructive review, discussion and insight in data, Prof. Dinu and D. Ciulavu for help during our field trips in Romania, and Marian Marunteanu (IGR) for fruitful discussion. Financial support was provided by The Netherlands Foundation for Scientific Research (NWO-GOA).

\section{References}

Andriessen, P. A. M.: Fission track analyses: principles, methodology and implications for tectono-thermal histories of sedimentary basins, orogenic belts and continental margins, Geol. Mijnb., 74, 1-12, 1995.

Babuska, V. and Plomerova, J.: Subcrustal continental lithosphere: a model of its thickness and anisotropic structure, Phys. Earth Planet. Inter., 51, 130-132, 1988.

Beaumont, C.: Foreland basins, Geophys. J. Roy. Astronom. Soc., 65, 291-329, 1981.

Beaumont, C., Fullsack, P., and Hamilton, J.: Erosional control of active compressional orogens, in: McClay, K. R. (Ed.): Thrust Tectonics, Chapman and Hall, New York, 1-18, 1992.

Bleahu, M., Lupu, M., Patrulius, D., Bordea, S., Stefan, A., Panin, S.: The structure of the Apuseni Mountains, Institute of Geol. and Geophys., Bucharest, 109 pp., 1981.

Ciulavu, D. and Bertotti, G.: The Transylvanian basin and its Upper Cretaceous substratum, Rom. J. Tect. Region, Geol., 75, suppl. 2, 59-64, 1994.

Ciulavu, D.: Tertiairy tectonics of the Transylvanian basin, Published PhD thesis, Vrije Universiteit Amsterdam, pp. 154, 1999.

Ciupagea, D., Pauca, M., and Ichim, T.: The geology of the Transylvanian depression (in Romanian), Editura Academiei Republici Socialiste Romania, Bucharest, 370 pp., 1970.

Cobbold, P. R., Davy, P., Gapais, D., Rossello, E. A., Sadybakasov, E., Thomas, J. C., Tondji Biyo, J. J., de Urreiztieta, M.: Sedimentary basins and crustal thickening, Sedim. Geol., 86, 77-89, 1993.

Codarcea, M., Savu, H., Pavelescu, M., Stancu, J., Lupu, D.: Geological map 1:200000, No. 26, Orastie, Geological Institute, Bucharest, 1968.

Cranganu, C. and Deming, D.: Heat Flow and Hydrocarbon Generation in the Transylvanian basin, Romania, Am. Assoc. Petrol. Geol.s Bull., 10, 1641-1653, 1996.

Csontos, L.:, Tertiary tectonic evolution of the Intra-Carpathian area: a review, Acta Vulcanologica, 7 (2), 1-13, 1995.

Davis, D., Suppe, J., and Dahlen, F. A.: Mechanics of Fold-andTrust Belts and Accretionary Wedges, J. Geophys. Res., 88, 1153-1172, 1983.

De Broucker, G., Mellin, A., and Duindam, P.: TectonoStratigraphic evolution of the Transylvanian basin, Pre-salt sequence, Romania, in: Dinu, C. and Mocanu, V. (Eds): Bucharest Geoscience Forum, Special Vol. 1, 36-70, 1998. 
DeCelles, P. G. and Giles, K. A.: Foreland basin systems, Basin Res., 8, 105-123, 1996.

Dercourt, J., Zonenshain, L. P., Ricou, L. E.: Geological evolution of the Tethys belt from the Atlantic to the Pamirs since the Lias, Tectonophysics, 123, 241-315, 1986.

Dövenyi, P. and Horvath, F.: A Review of Temperature, Thermal Conductivity, and Heat Flow data for the Pannonian Basin, in: Royden, L. H. and Horvath, F. (Eds.): The Pannonian Basin, a Study in Basin Evolution, Am. Assoc. Petrol. Geol. Mem., 195234, 1988.

Ellouz, N. and Roca, E.: Palinspastic Reconstructions of the Carpathians and Adjacant Areas since the Cretaceous: a Quantitative Approach, in: Roure, F. (Ed.): Peri-Tethyan Platforms, Editions Technip, Paris, 51-78, 1994.

Galbraith, R.: On statistical models for fission track counts, Math. Geol., 13, 471-488, 1981.

Gurnis, M.: Rapid Continental Subsidence Following the Initiation and Evolution of Subduction, Science, 255, 1556-1558, 1992.

Gyorfi, I. and Csontos, L.: Structural evolution of SE Hungary and Neogene basins of the Apuseni mountains (Romania), Rom. J. Tect. Region. Geol., 75(1), 19-20, 1994.

Haq, B. U., Hardenbol, J., and Vail, P. R.: Chronology of fluctuating sealevels since the Triassic (250 million years ago to present), Science, 235, 1156-1167, 1987.

Horvath, F.: Towards a mechanical model for the formation of the Pannonian basin, Tectonophysics, 226, 333-357, 1993.

Huismans, R. S., Bertotti, G., Ciulavu, D., Sanders, C. A. E., Cloetingh, S. A. P. L., and Dinu, C.: Structural evolution of the Transylvanian Basin (Romania): a sedimentary basin in the bend zone of the Carpathians, Tectonophysics, 272, 249-268, 1997.

Huismans, R. S., Podladchikov, Y. Y., and Cloetingh, S. A. P. L.: The transition from passive to active rifting. FEM modelling of convective upwelling of mantle lithosphere beneath rift zones, Tectonophysics, submitted, 1998.

Huismans, R. S.: Tectonic modelling of mantle lithosphere beneath rift zones, Published PhD thesis, Vrije Universiteit Amsterdam, pp. $182,1999$.

Johnson, D. D., and Beaumont, C.: Preliminary results from a planform kinematic model of orogen evolution, surface processes and the development of clastic foreland basin stratigraphy, in: Stratigraphic evolution of Foreland basins, SEPM Special Publication No. 52, 3-24, 1995.

Jordan, T. E.: Retroarc Foreland and Related Basins, in: Busby, C. J. and Ingersoll, R. V. (Eds.): Tectonics of Sedimentary Basins, Blackwell Science, Cambridge, 331-362, 1995.

Koch, A.: Die Teriaerbildungen des Beckens der Siebenburgischen Landestheile. II. Neogene Abtheilung, Hungarischen Geologischen Gesellschaft, Budapest, 1900.

Lankreijer, A., Mocanu, V., and Cloetingh, S. A. P. L.: Lateral variations in lithosphere strength in the Romanian Carpathians: constraints on basin evolution, Tectonophysics, 272, 269-290, 1997.

Lankreijer, A.: Rheology and basement control on extensional basin evolution in Central and Eastern Europe: Variscan and Alpine Carpathian Pannonian tectonics, Published PhD thesis, Vrije Universiteit, Amsterdam, 157 pp, 1998.

Mahel, M.: Tectonic map of the Carpathian Balkan mountain system and adjacent areas, Stur's Geological Institute and UNESCO, Bratislava, 1973.

Marinescu, F., Ghenea, C., and Papaianopol, I.: Stratigraphy of the Neogene and the Pleistocene Boundary, Inst. Geol. and Geophys., Bucharest, 112 pp., 1981.

Marinescu, F., Ticleanu, N., and Papaianopol, I.: Paysages Sarma- tien en Romanie, in: The Miocene from the Transylvanian BasinRomania , Institute of Geology and Geophysics, Cluj-Napoca, (in French), 1994.

Marunteanu, M.: Paleo-geographical maps of Romania, in prep., 1997.

Matenco, L., Zoetemeyer, R., Cloetingh, S. A. P. L., and Dinu, C.: Lateral variations in mechanical properties of the Romanian Outer Carpathians: inferences of flexure- and gravity modelling, Tectonophysics, 282, 147-166, 1998.

Mitrovica, J. X., Beaumont, C., Jarvis, G. T.: Tilting of continental interiors by the dynamic effects of subduction, Tectonics, 8 , 1079-1094, 1989.

Mocanu, V. and Radulescu, F.: Geophysical features of the Romanian territory., Rom. J. Tect. Region. Geol., 75, suppl. 2, 17-36, 1994.

Nagymarosy, A. and Baldi-Beke, M.: The Szolnok unit and its probable paleogeographic position, Tectonophysics, 226, 457470, 1993.

Peper, T., van Balen, R., and Cloetingh, S. A.P. L.: Implications of Orogenic Wedge Growth, Intraplate Stress Variations, and Eustatic Sea-Level Change for Foreland Basin StratigraphyInferences From Numerical Modeling, in: Dorobek, S. L., and Ross, G. M. (Eds.): Stratigraphic Evolution of Foreland Basins, Society for Sedimentary Geology, Tulsa, 25-36,1995.

Platt, J. P.: Dynamics of orogenic wedges and the uplift of highpressure metamorphic rocks, Geol. Soc. Am. Bull., 97, 10371053, 1986.

Pospisil, L. and Vass, D.: Influence of the lithosphere on the formation and development of intramontane and back molasse basins of the Carpathian Mountains, Geophys. Trans., 30, 355-372, 1984.

Roure, F., Roca, E., and Sassi, W.: The Neogene evolution of the outer Carpathian flysch units (Poland, Ukraine and Romania): kinematics of a foreland/fold-and-thrust belt system, Sed. Geol., 86, 177-201, 1993.

Royden, L.: Late Cenozoic Tectonics of the Pannonian Basin System, Am. Assoc. Petrol. Geol. Memoir, 45, 27-48, 1988.

Sachsenhofer, R. F., Lankreyer, A., Cloetingh, S. A.P.L., and Ebner, F.: Subsidence analysis and quantitative basin modelling in the Styrian Basin (Pannonian Basin System, Austria), Tectonophysics, 272, 175-196, 1996.

Sandulescu, M., Kräutner, H., Borcos, M., Nastaseanu, S., Patrulius, D., Stefanescu, M., Ghenea, C., Lupu, M., Savu, H., Bercia, I., and Marinescu, F.: Geological map of Romania 1:1 000 000, Institutul de Geologie si Geofizica, Bucharest, 1978.

Sandulescu, M.: Cenozoic Tectonic History of the Carpathians, Am. Assoc. Petrol. Geol. Mem., 45, 17-25, 1988.

Sanders, C. A.E.: Tectonics and Erosion, Competitive forces in a compressive orogen. A fission track study of the Romanian Carpathians, Published PhD thesis, Vrije Universiteits, Amsterdam, pp. 204, 1998.

Sanders, C. A.E., Andriessen, P. A. M., and Cloetingh, S.A.P.L.: Life cycle of the East Carpathian orogen: Erosion history of a doubly vergent critical wedge assessed by fission track thermochronology, J. Geophys. Res., 104, B12, 29 095-29112, 1999.

Schlunegger, F., Jordan, T. E., and Klaper, E. M.: Controls of erosional denudation in the orogen on foreland basin evolution: The Oligocene central Swiss Molasse Basin as an example, Tectonics, 16, 823-840, 1997.

Stefanescu, M.: O noua imagine a structurii flisului intern din regiunea de curbura a Carpatilor (in Romanian), Dari de Seama 
ale Sedintelor, 62, Institutul de Geologie si Geofizica, Bucharest, 257-279, 1976.

Stefanescu, M.: Elaborarea Profilelor, Scara 1:200 000 pentru Completarea Imaginii Geologice a Teritoriului R. S. Romania (A-9,10,-11,-12,-14,-18,-20), Institul de Geologie si Geofizica, Bucharest, 1985 .

Steininger, F. F., Müller, C., and Rögl, F.: Correlation of Central Parathethys, Eastern Parathetys, and Mediterrenean Neogene Stages, in: Royden, L. H. and Horvath, F. (Eds.): The Pannonian Basin, a Study in Basin Evolution, Am. Assoc. Petrol. Geol. Memoir, 79-88, 1988.

Tari, G., Horvath, F., Rumpler, J.: Styles of extension in the Pannonian Basin, in: Ziegler, P. A. (Ed.): Geodynamics of Rifting, Volume I. Case History Studies on Rifts: Europe and Asia. Tectonophysics, 208, 203-219, 1992.

Van der Beek, P., Cloetingh, S. A. P. L., and Andriessen, P. A. M.:
Mechanisms of extensional basin formation and vertical motions at rift flanks: Constraints from tectonic modelling and fission track thermochronology, Earth Planet. Sci. Lett., 121, 417-433, 1994.

Van Wees, J. D., Cloetingh, S. A.P.L., and de Vicente, G.: The role of pre-existing faults in basin evolution: constraints from $2 \mathrm{D}$ finite element and 3D flexure models, in: Buchanan, P. G. and Nieuwland, D. A. (Eds.): Modern Developments in Structural Interpretation, Validation and Modelling, 297-320, 1996.

Veliciu, S.: Geothermics of the Carpathian area, Anuarul Institutului de Geologie si Geofizica, 67, 81-117, 1987.

Willet, S., Beaumont, C., and Fullsack, P.: Mechanical model for the tectonics of doubly vergent compressional orogens, Geology, 21, 371-374, 1993.

Zoetemeijer, R.: Tectonic modelling of foreland basins, Published $\mathrm{PhD}$ thesis, Vrije Universiteit, Amsterdam, 148 pp, 1993. 